\title{
New species and new records of linyphiid spiders from Israel (Aranei: Linyphiidae)
}

\author{
Новые виды и новые находки пауков-Аинифиид из Израиля \\ (Aranei: Linyphiidae)
}

\author{
Andrei V. Tanasevitch \\ Андрей В. Танасевич
}

\begin{abstract}
A.N. Severtsov Institute of Ecology and Evolution, Russian Academy of Sciences, Leninsky prospekt, 33, Moscow 119071, Russia. E-mail: tanasevitch@gmail.com

Институт проблем экологии и эволюции им. А.Н. Северцова РАН, Ленинский проспект, 33, Москва 119071, Россия.
\end{abstract}

KEY WORDS: Spiders, Erigoninae, new species, new records, Levant.

КЛЮЧЕВЫЕ СЛОВА: Пауки, Erigoninae, новые виды, новые находки, Левант.

ABSTRACT. Four new species of linyphiid spiders are described from Israel: Pelecopsis levantensis sp.n., Silometopus minutus sp.n., S. pectinatus sp.n. and Walckenaeria galilea sp.n. Three species, Brachycerasphora convexa (Simon, 1884), B. parvicornis (Simon, 1884) and Thaumatoncus secundus Bosmans, 2002, are recorded from the country for the first time. A supplemented list of 43 linyphiid spiders of Israel is given, coupled with their distribution patterns. The linyphiid fauna of Israel can preliminarily be characterized as Mediterranean, with a high proportion of presumed Levantine faunistic elements $(28 \%)$ and a very low share of widespread species $(9 \%)$. The influence of the North African centre of linyphiid diversity on the western Levantine linyphiid fauna is expressed much more strongly than that of the Central Asian one.

РЕЗЮМЕ. Из Израиля описаны Pelecopsis levantensis sp.n., Silometopus minutus sp.n., S. pectinatus sp.n. и Walckenaeria galilea sp.n. Три вида, Brachycerasphora convexa (Simon, 1884), B. parvicornis (Simon, 1884) и Thaumatoncus secundus Bosmans, 2002, впервые отмечены в фауне страны. Приведен обновлённый и дополненный список 43 видов линифиид Израиля с указанием типа ареала. Фауну Израиля в целом можно охарактеризовать как средиземноморскую, с высокой долей видов, вероятно, левантийского распространения (28\%) и малым участием широкоареальных элементов (9\%). Влияние североафриканского центра разнообразия Linyphiidae в фауне Западного Леванта ощущается существенно явственнее, чем центральноазиатского.

\section{Introduction}

A rather recently published checklist of the spiders of Israel [Zonstein, Marusik, 2013] contained 23 spe- cies of linyphiid spiders, four of which remained identified to the generic level only. In addition, Tanasevitch [2013] described six new linyphiid species from Israel and recorded another 12 species as new to the country. Zonstein et al. [2015] supplemented the fauna with still one more species. As a result, at the moment the fauna of Israel counts 37 linyphiids identified to species.

\section{Material and methods}

This paper is mainly based on the material kept at the Steinhardt Museum of Natural History, Tel Aviv, Israel (SMNH). Additional samples were collected by Sergei Golovatch in 2003 and by Andrei Tanasevitch, Tatiana Piterkina and Sergei Zonstein during their brief collecting trip across Israel in September 2011.

Most of the material is deposited in the SMNH, some paratypes and non-types are in the collections of the Muséum d'histoire naturelle, Geneva, Switzerland (MHNG), and of the Zoological Museum of the Moscow State University, Moscow, Russia (ZMMU).

Specimens preserved in $70 \%$ ethanol were studied using a MBS-9 stereomicroscope and a Wild compound microscope. A Levenhuk C-800 digital camera was used for the execution of some drawings. Images of multiple focal sections were combined using Helicon Focus image stacking software, version 5.3.

The terminology concerning the structure of the copulatory organs mainly follows that of Merrett [1963] and Hormiga [2000].

The chaetotaxy is given in a formula, e.g., 2.2.1.1, which refers to the number of dorsal spines on tibiae IIV. The sequence of leg segment measurements is as follows: femur + patella + tibia + metatarsus + tarsus. All measurements are given in $\mathrm{mm}$. Scale bars in the figures correspond to $0.1 \mathrm{~mm}$ unless indicated below the line. 


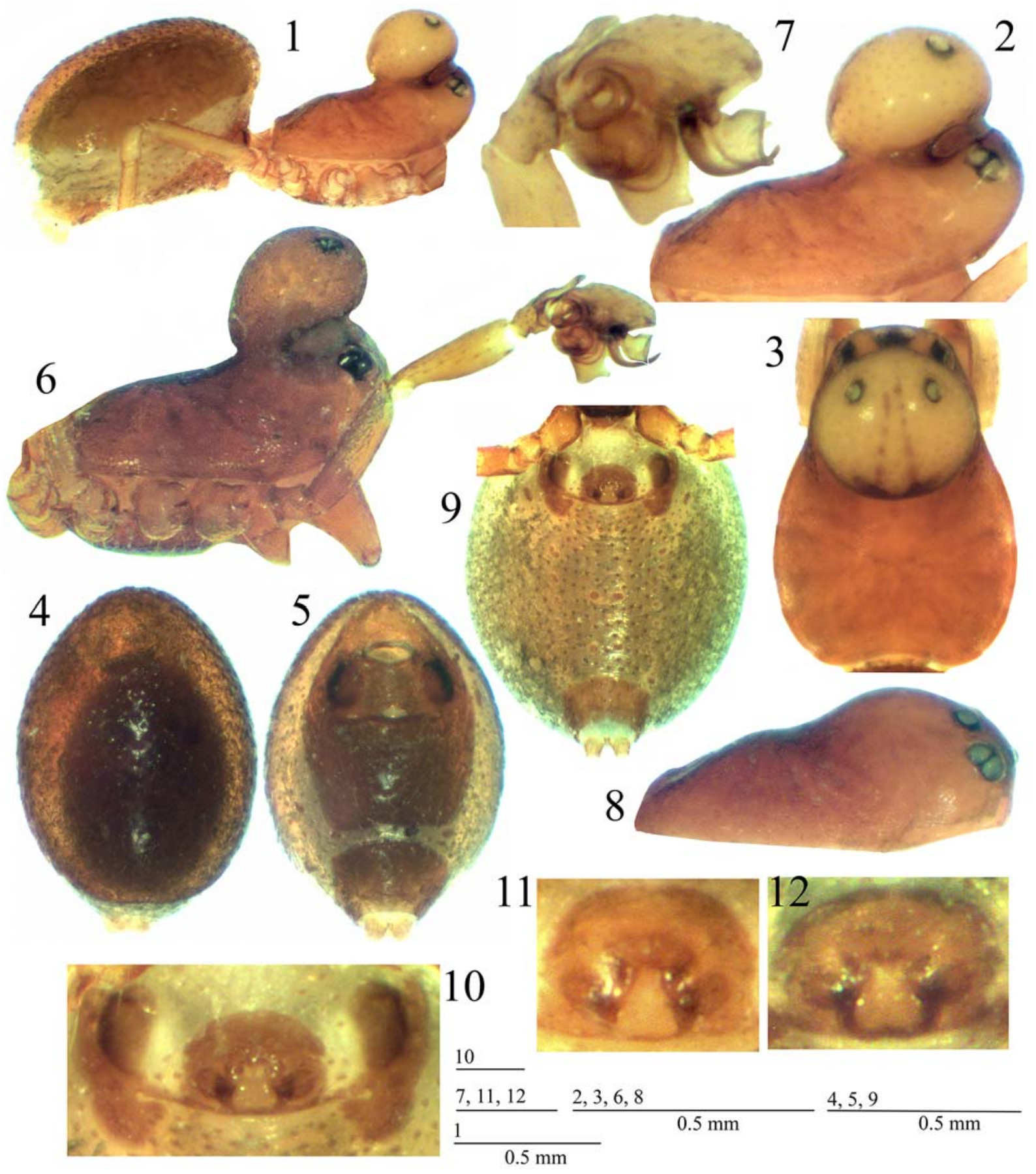

Figs 1-12. Pelecopsis levantensis sp.n., paratypes from En Ya'aqov (1-6, 7-12) and from Mt Meron (6). 1-3, 6 - male carapace, 1, 2, 6 - lateral view, 3 - dorsal view; 8 - female carapace, lateral view; 4, 5 - male abdomen, dorsal and ventral views, respectively; 9 - female abdomen, ventral view; 10-12 - epigyne, ventral view.

Рис. 1-12. Pelecopsis levantensis sp.n., паратипы из En Ya'aqov (1-6, 7-12) и с горы Мерон (6). 1-3, 6 - карапаксы самцов, 1, 2, 6 - вид сбоку, 3 - вид сверху; 8 - карапакс самки, вид сбоку; 4, 5- брюшко самца, вид сверху и снизу, соответственно; 9 брюшко самки, вид снизу; 10-12 - эпигина, вид снизу. 


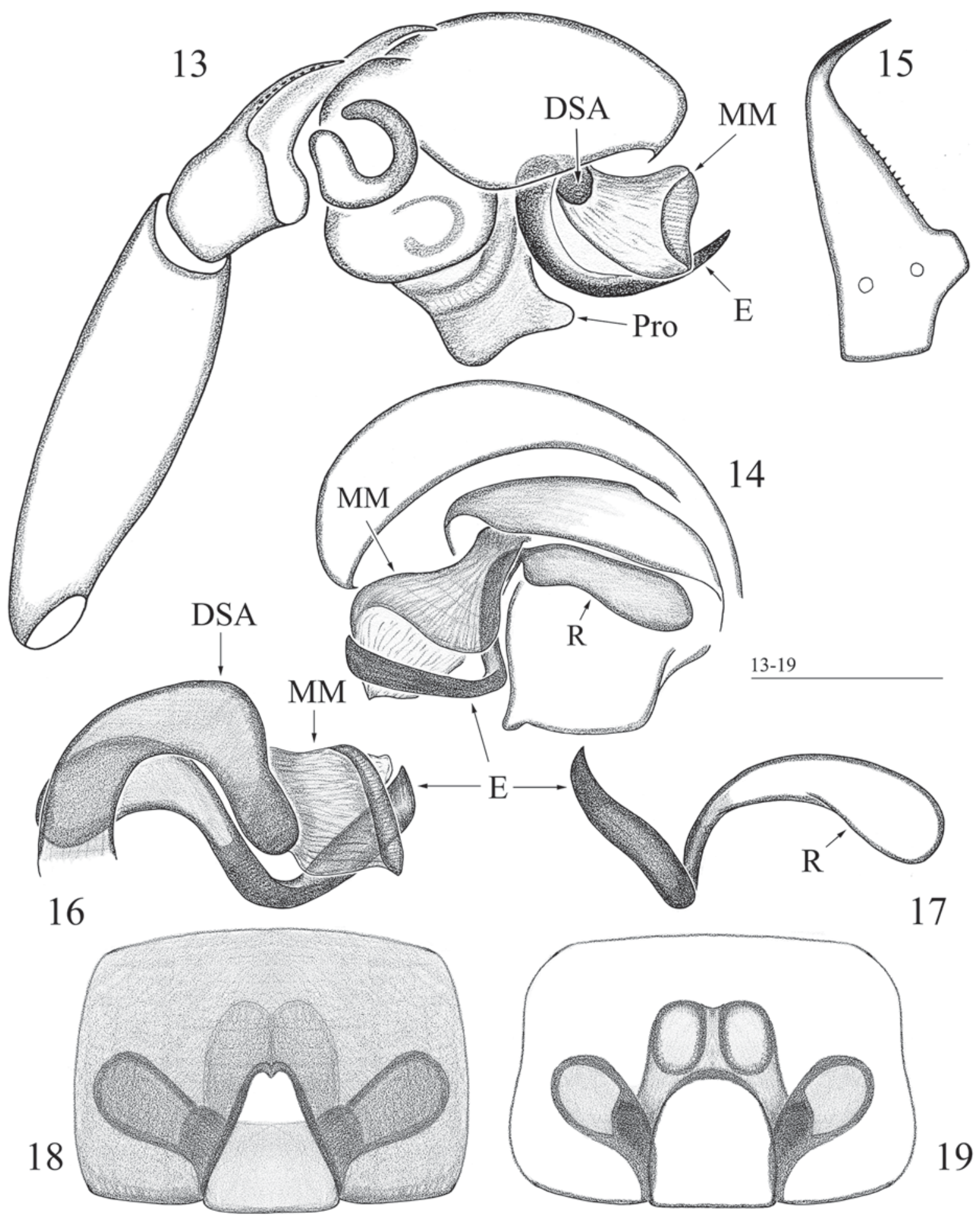

Figs 13-19. Details of male palp structure and epigyne of Pelecopsis levantensis sp.n., paratypes from En Ya'aqov. 13, 14 - right palp, retro- and prolateral views, respectively; 15 - palpal tibia, dorsal view; 16 - distal suprategular apophysis and embolus; 17 embolus; 18 - epigyne ventral view; 19 - cleared epigyne, dorsal view.

Рис. 13-19. Детали строения пальпы самца и эпигины самки Pelecopsis levantensis sp.n., паратипы из En Ya'aqov. 13, 14 правая пальпа, ретро- и пролатерально, соответственно; 15 - голень пальпы, вид сверху; 16 - дистальный супратегулярный отросток и эмболюс; 17 - эмболюс; 18 - эпигина, вид снизу; 19 - просветлённая эпигина, вид сверху. 


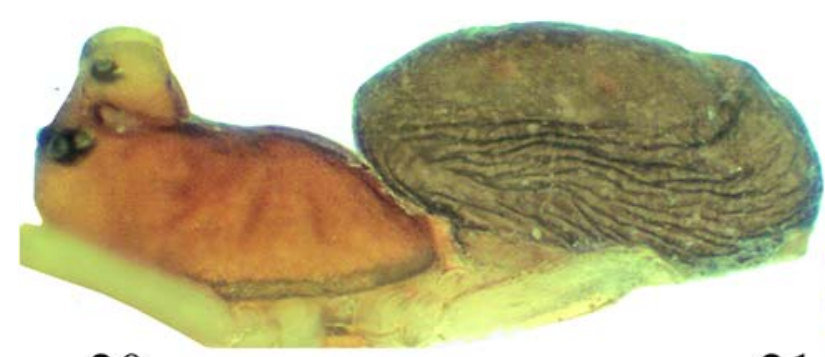

20

20-23

$0.50 \mathrm{~mm}$

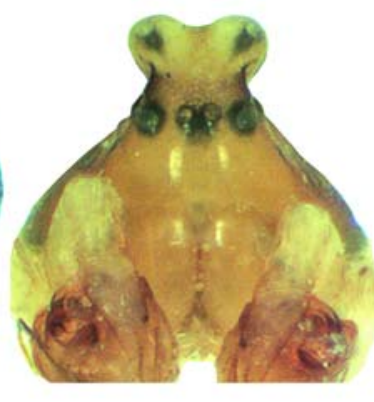

22
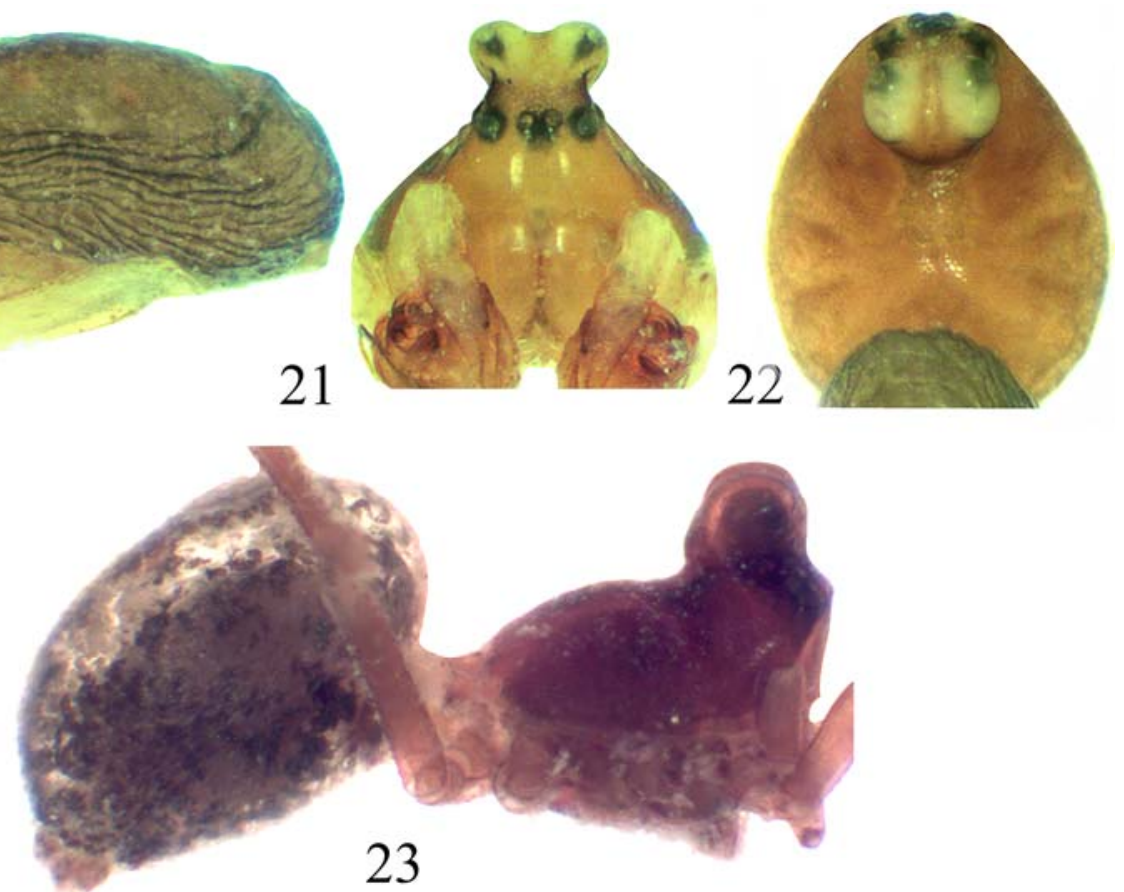

23

Figs 20-23. Male body and carapace of Silometopus minutus sp.n., holotype (20-22) and S. pectinatus sp.n., holotype (23). 20, 23 body, lateral view; 21, 22 - carapace, frontal and dorsal views, respectively.

Рис. 20-23. Тело и карапакс самца Silometopus minutus sp.n., голотип (20-22) и S. pectinatus sp.n., голотип (23). 20, 23 - тело, вид сбоку; 21, 22 - карапакс, вид спереди и сверху, соответственно.

The following abbreviations are used in the text and figures: ARP — anterior radical process; DSA distal suprategular apophysis; E - embolus; MM median membrane; Pro - protegulum; $\mathrm{R}$ - radix; $\mathrm{TmI}$ - position of trichobothrium on metatarsus I.

\section{Results}

Brachycerasphora convexa (Simon, 1884)

MATERIAL. $1 \sigma^{7}, 2$ 우 (SMNH), ISRAEL, ca $10 \mathrm{~km} \mathrm{SSW} \mathrm{of}$ Beit-Shemesh, Adullam Nature Park, 15.XI.2003, leg. U. Columbus \& T. Levanony; $1 \mathrm{O}^{T}$ (SMNH), environs of Shoham, 25.II.2011, leg. C. Drees; 1 O, 1 (SMNH), Upper Galilee, environs of En Ya'aqov, $33^{\circ} 0^{\prime} 27.5^{\prime \prime} \mathrm{N} 35^{\circ} 14^{\prime} 20.0^{\prime \prime} \mathrm{E}$, pitfall traps, 14-19.I.2007, leg. I. Shtirberg.

REMARKS. New to the Israeli fauna.

DISTRIBUTION. Algeria [Simon, 1884; Bosmans, 2007], Tunisia [Bosmans, 2007] and Israel.

\section{Brachycerasphora parvicornis (Simon, 1884)}

MATERIAL. $10^{7}$ (SMNH), ISRAEL, Central Negev Desert, Sede Boqer, $30^{\circ} 52^{\prime} 3.1^{\prime \prime} \mathrm{N} 34^{\circ} 46^{\prime} 17.8^{\prime \prime} \mathrm{E}$, pitfall traps, 3-8.II.2007, leg. I. Shtirberg.

REMARKS. New to the Israeli fauna.

DISTRIBUTION. Egypt [Simon, 1884] and Israel.

Maculoncus parvipalpus Wunderlich, 1995

MATERIAL. $1 \sigma^{7}, 2$ 오 (SMNH), ISRAEL, Adullam Nature Park, 15.IV.2003, leg. U. Columbus \& T. Levanony; $1 \sigma^{7}, 1$ 9

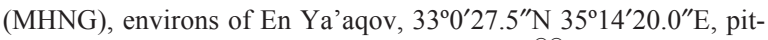
fall trap 11, 14-19.I.2007, leg. I. Shtirberg; 2 우 (SMNH), Zihron Ya'aqov, environs of the Rotshild Park, 11.IX.2011, leg. A. Tanasevitch \& T. Piterkina.

REMARKS. In Israel this species has hitherto been reported from Haifa, based on a single female [Zonstein et al., 2015].

DISTRIBUTION. Greece [Wunderlich, 1995], including Crete [Bosmans et al., 2013], as well as Israel [Zonstein et al., 2015].

\section{Pelecopsis levantensis sp.n.}

Figs 1-19.

HOLOTYPE $0^{7}$ (SMNH), $8 \mathrm{~km}$ SE of Beit-Shemesh, environs

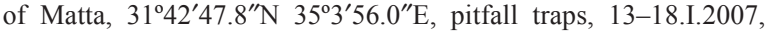
leg. I. Shtirberg.

PARATYPES. $4 \mathrm{O}^{7} \mathrm{O}^{7}, 2$ 우 (SMNH), same date and locality, 13-18.I.2007, leg. I. Shtirberg; 20 우 (SMNH), ca $10 \mathrm{~km} \mathrm{SSW} \mathrm{of}$ Beit-Shemesh, Adullam Nature Park, pitfall traps, III-IV.2003, leg, U. Columbus \& T. Levanony; $16{O^{7}}^{7}, 18$ of (MHNG), Upper Galilee, environs of En Ya'aqov, $33^{\circ} 0^{\prime} 27.5^{\prime \prime} \mathrm{N} 35^{\circ} 14^{\prime} 20.0^{\prime \prime} \mathrm{E}$, pitfall traps, 14.I-19.IV.2007, leg. I. Shtirberg; $3 \mathrm{O}^{\top} \sigma^{\top}, 13$ 우 (ZMMU), Upper Galilee, Mt Meron, Meron Field Station junction, 33 ${ }^{\circ} 1^{\prime}$ $16.62^{\prime \prime} \mathrm{N} 35^{\circ} 22^{\prime} 56.59^{\prime \prime} \mathrm{E}$, pitfall traps, 17-24.II.2007, leg. T. Levanony; 1 ( $\mathrm{SMNH})$, Ziv'on, $33^{\circ} 02^{\prime} \mathrm{N} 35^{\circ} 25^{\prime} \mathrm{E}, 773 \mathrm{~m}$ a.s.l., recent woodland, 21.V.2005, leg. A. Timm;1 $\sigma^{7}$ (SMNH), Mt Carmel, 22.II.2011, leg. C. Drees; $1 \mathrm{O}^{\top}$ (ZMMU), Nahal Hagal, ca. $32^{\circ} 38.0^{\prime} \mathrm{N} 35^{\circ} 32.7^{\prime} \mathrm{E}, 30 . I .2011$, leg. L. Friedman \& C. Drees.

NAME. The specific name is a Latin adjective, meaning the historical region of Levant. 


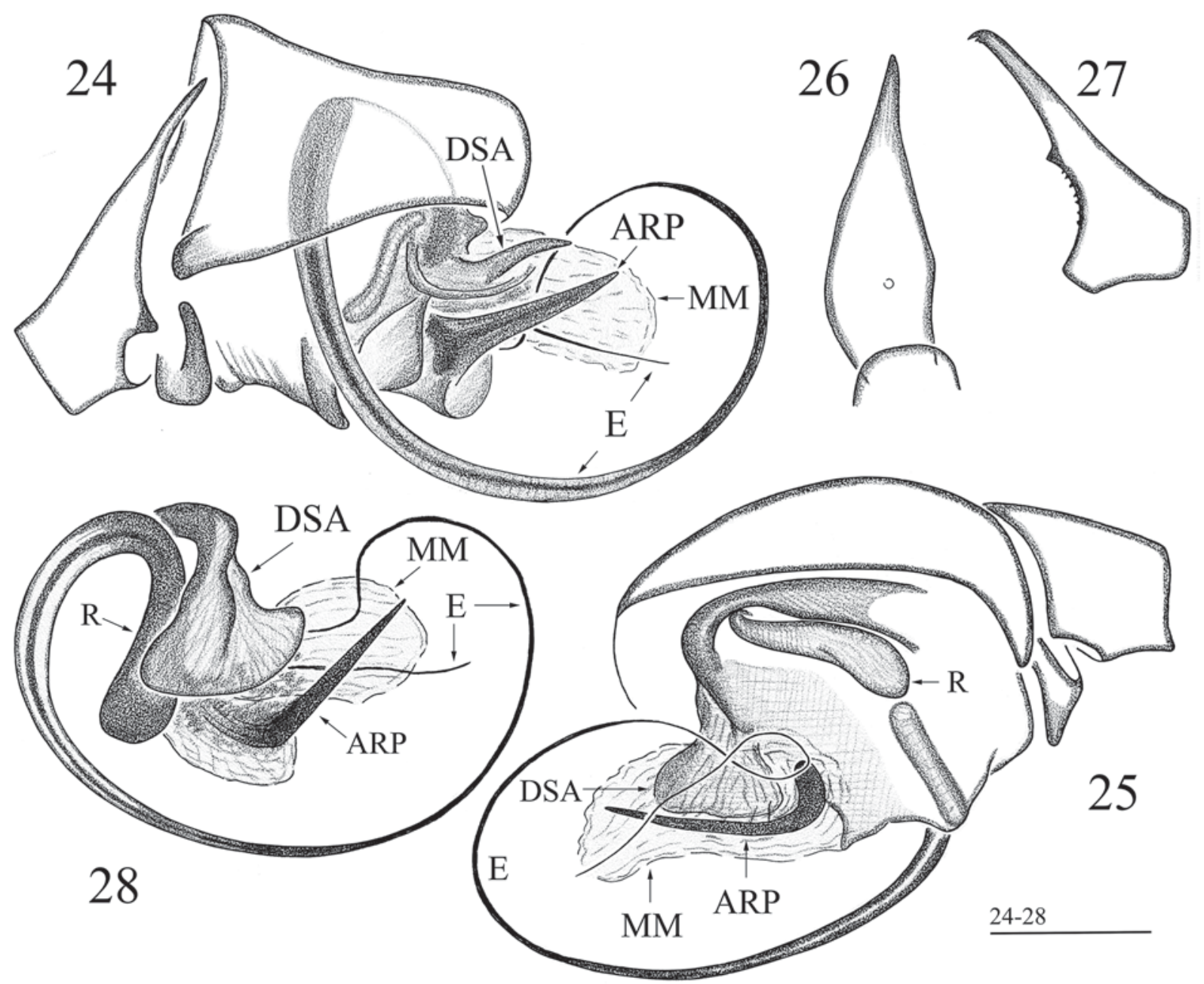

Figs 24-28. Details of male palp structure of Silometopus minutus sp.n., holotype. 24, 25 - right palp, retro- and prolateral views, respectively; 26, 27 - palpal tibia, dorsal and prolateral views, respectively; 28 - distal suprategular apophysis and embolic division.

Рис. 24-28. Детали строения пальпы самца Silometopus minutus sp.n., голотип. 24, 25 - правая пальпа, ретро- и пролатерально, соответственно; 26, 27 - голень пальпы, вид сверху и пролатерально, соответственно; 28 - дистальный супратегулярный отросток и эмболюсный отдел.

DESCRITION. Male paratype from Matta. Total length 1.71. Carapace modified, as in Figs $1-3,0.80$ long, 0.60 wide, reddish brown. Chelicerae 0.20 long, unmodified. Legs brownish yellow. Leg I, 1.61 long $(0.44+0.18+0.38+0.32+0.29), \mathrm{IV}, 1.87$ long $(0.56+$ $0.17+0.53+0.35+0.26)$. Chaetotaxy 0.0.0.0. TmI 0.55 . Metatarsus IV without trichobothrium. Palp (Figs 7, 13-17): Palpal tibia elongated conically, bent distally, pointed. Paracymbium small, narrow, coiled. Tegulum with a distinct, well protruded protegulum. Distal suprategular apophysis relatively short, rounded distally. Median membrane highly developed, moderately sclerotized, protruding anteriorly, partly covering the embolus. Radix elongated, almost straight, embolus relatively thick and short, regularly curved. Abdomen 1.00 long, 0.75 wide, dorsal scutum covering almost entire dorsal surface of abdomen (Fig. 4), ventral scutum divided into two parts (Fig. 5).
Female. Total length 1.98. Carapace modified, as in Fig. 8, 0.81 long, 0.65 wide, reddish brown. Chelicerae 0.29 long, unmodified. Legs brownish yellow. Leg I, 1.85 long $(0.60+0.18+0.45+0.36+0.26)$, IV, 2.19 long $(0.65+0.21+0.60+0.45+0.28)$. Chaetotaxy 1.1.1.1, spines very weak, about half as long as tibia's diameter. TmI 0.50. Abdomen (Fig. 9) 1.23 long, 0.96 wide, dorsal scutum absent. Epigyne as in Figs 10-12, 18, 19.

VARIABILITY. The shape of the head elevation, as well as the shape and size of the sulci of the male carapace slightly vary, cp. Figs 1, 2 \& Fig. 6. The protegulum also shows variability in size. The epigynes vary in length and in the degree of expression of their anterior sockets, cp. Figs 10-12, 18.

TAXONOMIC REMARKS. By the shape of the male carapace as well as by certain details of genital structure, $P$. levantensis sp.n. resembles many species. 


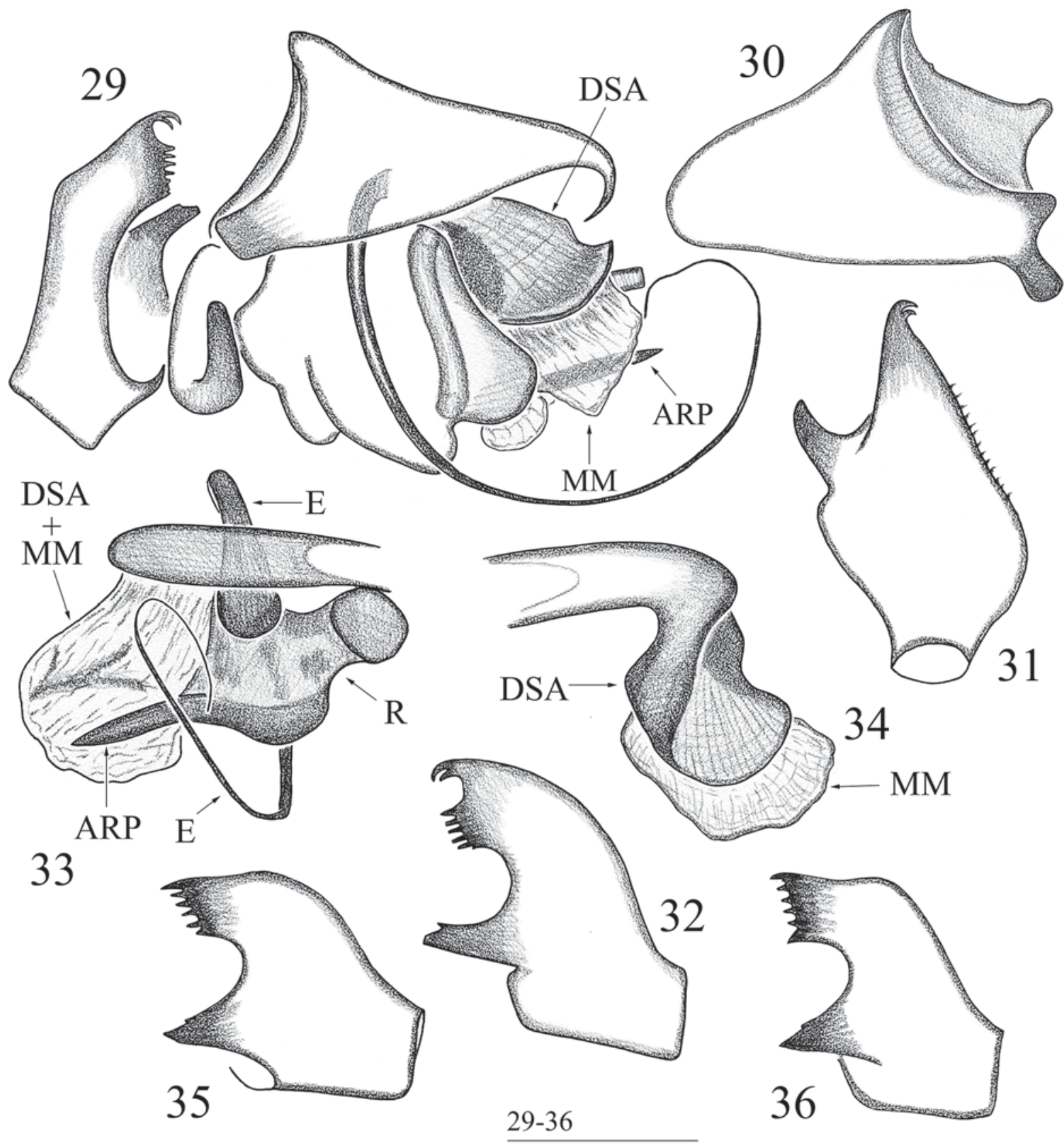

Figs 29-36. Details of male palp structure of Silometopus pectinatus sp.n., paratypes. 29 — right palp, retrolateral view; 30 cymbium, prolateral view; 31, 32 - palpal tibia, dorsal and prolateral views, respectively; 33 — distal suprategular apophysis and embolic division; 34 - distal suprategular apophysis and median membrane; 35, 36 - palpal tibia of two other paratypes, prolateral view.

Рис. 29-34. Детали строения пальпы самца Silometopus pectinatus sp.n., паратипы. 29 - правая пальпа, ретролатерально; 30 - цимбиум, пролатерально; 31, 32 - голень пальпы, вид сверху и пролатерально; 33 - дистальный супратегулярный отросток и эмболюсный отдел; 34 - дистальный супратегулярный отросток и медиальная мембрана; 35,36 - голень пальпы двух других паратипов, пролатерально.

For example, the shape of the male carapace is similar to that of P. crassipes Tanasevitch, 1987 and Parapelecopsis nemoralis (Blackwall, 1841), the palpal tibia resembles that of $P$. elongata (Wider, 1834), the structure of the median membrane looks very much like in $P$. bicornuta Hillyard, 1980, P. laptevi Tanasevitch et Fet, 1986 and P. pavida (O. Pickard-Cambridge, 1872).
The new species is characterized by a combination of the following features: the shape of the male carapace and palpal tibia, the presence of a ventral abdominal scutum, the absence of a posterodorsal outgrowth on the cymbium, the well-developed protegulum, the shape both of the median membrane and embolic division. The structure of the epigyne is also characteristic. 


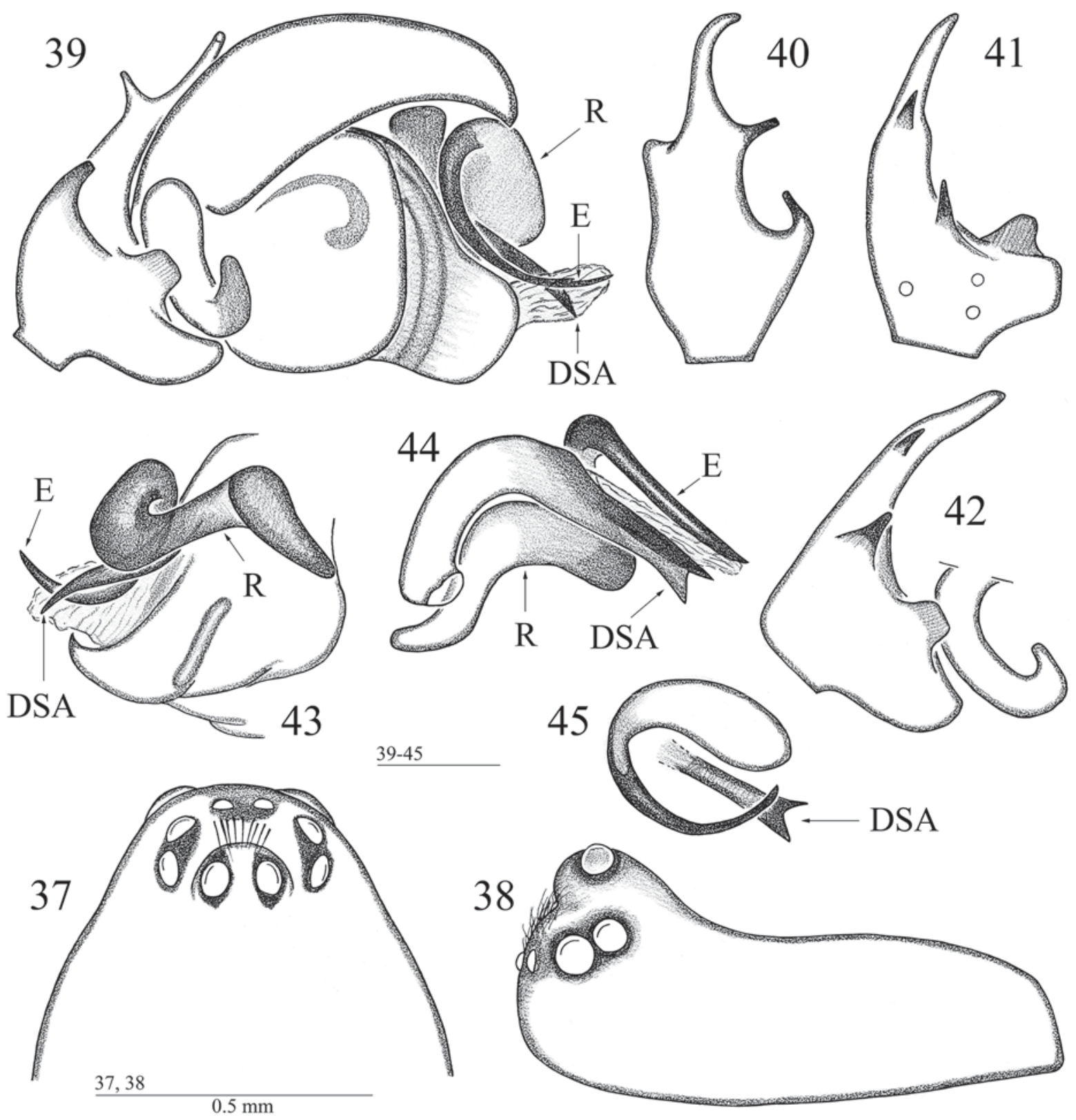

Figs 37-45. Carapace and details of male palp structure of Walckenaeria galilea sp.n., holotype. 37, 38 - carapace, dorsal and lateral views, respectively; 39 - right palp, retrolateral view; 40, 41 - palpal tibia, dorsal view, different aspects; 42 - palpal tibia and paracymbium, retrolateral view; 43 - anterior part of palp, prolateral view; 44, 45 - distal suprategular apophysis and embolus, lateral and frontal views, respectively.

Рис. 37-45. Карапакс и детали строения пальпы самца Walckenaeria galilea sp.n., голотип. 37, 38 - карапакс, вид сверху и сбоку, соответственно; 39 - правая пальпа, ретролатерально; 40, 41 - голень пальпы, вид сверху, различные аспекты; 42 голень пальпы и парацимбиум, ретролатерально; 43 - передняя часть пальпы, пролатерально; 44, 45 — дистальный супратегулярный отросток и эмболюс, вид сбоку и спереди, соответственно.

DISTRIBUTION. Widespread in Israel.

\section{Silometopus minutus sp.n.}

Figs 20-22, 24-28.

HOLOTYPE $\sigma^{7}$ (SMNH), ISRAEL, ca $10 \mathrm{~km}$ SSW of BeitShemesh, Adullam Nature Park, pitfall traps, IV.2003, U. Columbus \& T. Levanony.
NAME. The specific name is a Latin adjective, meaning a small size of the male.

DESCRITION. Male holotype. Total length 1.32 . Carapace modified, as in Figs. 20-22, 0.63 long, 0.57 wide, pale reddish brown. Chelicerae 0.23 long, unmodified. Legs pale yellow. Leg I, 1.76 long $(0.48+$ $0.17+0.48+0.36+0.27)$, IV, 1.88 long $(0.54+0.17+$ $0.48+0.39+0.30)$. Chaetotaxy 0.0.0.0. TmI 0.80 . 
Metatarsus IV without trichobothrium. Palp (Figs 2428): Palpal tibia elongated, narrow, pointed, with denticles apically. Cymbium conical, its proximal part with a hollow. Paracymbium small, narrow, C-shaped. Distal suprategular apophysis flat, wide. Median membrane large, partly membranized. Embolic division complex, radix partly membranized, anterior radical process dark, well-sclerotized, stylet-shaped. Embolus very long, whip-like, arising from radix. Abdomen 0.83 long, 0.53 wide, dark grey.

TAXONOMIC REMARKS. The new species is related to $S$. pectinatus sp.n. (see below).

DISTRIBUTION. Israel, known from the type locality only.

\section{Silometopus pectinatus sp.n.}

Figs 23, 29-36.

HOLOTYPE OT (SMNH), ISRAEL, Upper Galilee, Mt Meron, Ziv'on, 4-11.IV.2007, leg. T. Levanony.

PARATYPES. $2 \sigma^{7} \sigma^{7}$ (SMNH), $2 O^{7} \sigma^{7}$ (MHNG), $1 \sigma^{7}$ (ZMMU), collected together with holotype.

NOTE. The type series is in poor condition, the chitin cover of the carapace being always exfoliated and the legs mostly absent.

NAME. The specific name is a Latin adjective, meaning "pectinated", referring to the shape of the dorsal apophysis of the male palpal tibia.

DESCRITION. Male holotype. Total length 1.35. Carapace modified, as in Fig. 23, 0.60 long, 0.54 wide. Chelicerae 0.20 long, unmodified. Legs pale brown. Leg I, 1.61 long $(0.42+0.17+0.42+0.33+0.27)$, IV 1.73 long $(0.48+0.18+0.45+0.38+0.24)$. Chaetotaxy 0.0.0.0. TmI 0.82. Metatarsus IV without trichobothrium. Palp (Figs 29-36): Palpal tibia highly modified, its dorsal apophysis pectinated, comb-like. Paracymbium small, L-shaped. Cymbium conical, its proximal part with a hollow. Distal suprategular apophysis flat, wide. Median membrane well-developed.

Embolic division complex, radix partly membranized, anterior radical process dark, well-sclerotized, stylet-shaped. Embolus thin, long, whip-like, arising from radix. Abdomen 0.81 long, 0.53 wide, grey.

VARIABILITY. The shape of the dorsal apophysis of the palpal tibia, as well as the number of its denticles show strong variability, cp. Figs 32, 35, 36.

TAXONOMIC REMARKS. Both new Israeli species of Silometopus Simon, 1926, i.e. S. pectinatus sp.n. and S. minutus sp.n., differ well by the peculiar head elevation of the male carapace which resembles that in the genus Peponocranium Simon, 1884; by the conical cymbium, as well as by the very long, whiplike embolus. Both new species are distinguished from each other by the shapes of the palpal tibia (cp. Figs 26, $27 \& 32,35,36)$ and the head elevation of carapace (cp. Figs 20-22 \& Fig. 23).

DISTRIBUTION. Israel, known from the type locality only.

\section{Thaumatoncus secundus Bosmans, 2002}

MATERIAL. $3 O^{\top} O^{\top}$ (MHNG), ISRAEL, Central Negev Desert, Sede Boqer, $30^{\circ} 52^{\prime} 3.1^{\prime \prime} \mathrm{N} 34^{\circ} 46^{\prime} 17.8^{\prime \prime} \mathrm{E}$, pitfall traps, 13-18.I.2007, leg. I. Shtirberg; $1 \mathrm{O}^{7}$ (ZMMU), same locality, trap 9D, 3-8.II.2007, leg. I. Shtirberg; 8 O $^{\top} O^{7}$ (SMNH), Sede Boqer, 24.II.2011, leg. C. Drees.

REMARKS. New to the Israeli fauna.

DISTRIBUTION. Algeria [Bosmans, 2002] and Israel.

\section{Walckenaeria galilea sp.n.}

Figs 37-45.

HOLOTYPE $\sigma^{7}$ (SMNH), ISRAEL, Upper Galilee, environs of En Ya'aqov, $33^{\circ} 0^{\prime} 27.5^{\prime \prime} \mathrm{N} 35^{\circ} 14^{\prime} 20.0^{\prime \prime} \mathrm{E}$, pitfall traps, 14-19.I.2007, leg. I. Shtirberg.

PARATYPES. $1 \sigma^{\top}$ (SMNH), collected together with holotype; $4 \sigma^{\top} \sigma^{\top}$ (MHNG), Upper Galilee, Nahal Kzif Valley, pitfall traps, 22.II.2011, leg. leg. C. Drees; $2 \sigma^{7} \sigma^{7}$ (ZMMU), Mt Meron, N slope, Quercus forest, 6.III.2003, leg. S. Golovatch; 8 ○ $^{7}$ (SMNH), Mt Meron, Field Station junction, 33 ${ }^{\circ} 1^{\prime} 10.62^{\prime \prime} \mathrm{N} 35^{\circ} 23^{\prime} 12.17^{\prime \prime} \mathrm{E}$, pitfall traps, 17-24.II.2007, leg. T. Levanony.

NAME. The specific name, a noun in apposition, refers to the historical area of origin.

DESCRITION. Male holotype. Total length 2.40. Carapace slightly modified, as in Figs 37, 38, brownish red, 1.08 long, 0.80 wide. Chelicerae 0.40 long, unmodified. Legs reddish brown. Leg I, 3.36 long $(0.93+0.25+0.88+0.80+0.50)$, IV, 3.71 long $(1.03+0.28+1.00+0.90+0.50)$. Chaetotaxy: 2.2.1.1, spines weak, $0.5-1.0$ times as long as tibia's diameter, distal spines poorly visible. TmI 0.56. Metatarsus IV with a trichobothrium. Palp (Figs 39-45): Palpal tibia strongly modified, as in Figs 40-42. Paracymbium small, L-shaped. Tegulum with a frontal rounded protrusion. Distal suprategular apophysis long, narrow, bifid apically. Embolic division with a fusiform radix, embolus relatively short, coiled. Abdomen 1.25 long, 0.75 wide, grey.

VARIABILITY. The shape of the head elevation, the size and arrangement of the processes on the palpal tibia are rather stable and fail to vary.

TAXONOMIC REMARKS. $W$. galilea sp.n. seems to be very similar to the Cyprian $W$. cyprusensis Wunderlich, 1995, but can be distinguished by the shape of the head elevation, by the arrangement of apophyses on the palpal tibia, by the relatively large embolic circle, as well as by the chaetotaxy formula typical of the genus, i.e. 2.2.1.1, versus 1.1.1.1 in $W$. cyprusensis.

DISTRIBUTION. Israel, known from the type locality only.

\section{Conclusion}

The linyphiid spider fauna of Israel is currently known to contain 43 species (see Table). The Israeli fauna can generally be characterized as Mediterranean, with a low proportion (9\%) of widespread (cosmopolitan, Holarctic and Palaearctic) species. In contrast, the share of presumed Levantine elements $(28 \%)$ is essen- 
Table. A list of the linyphiid spiders of Israel with their distribution patterns.

Таблица. Список видов пауков-линифиид Израиля с типами их ареалов.

\begin{tabular}{|c|c|}
\hline Species & Distribution pattern \\
\hline Agyneta pseudorurestris (Wunderlich, 1980) & Mediterranean \\
\hline Alioranus pastoralis (O. Pickard-Cambridge, 1872) & East Ancient Mediterranean \\
\hline Araeoncus banias Tanasevitch, 2013 & Levantine \\
\hline Archaraeoncus hebraeus Tanasevitch, 2011 & Levantine \\
\hline Brachycerasphora convexa (Simon, 1884) & Mediterranean \\
\hline B. femoralis (O. Pickard-Cambridge, 1872) & Levantine \\
\hline B. parvicornis (Simon, 1884) & East Mediterranean \\
\hline Canariphantes epigynatus T anasevitch, 2013 & Levantine \\
\hline C. nanus (Kulczyński, 1898) & East Mediterranean \\
\hline Cresmatoneta mutinen sis (Canestrini, 1868) & Mediterranean \\
\hline Dactylopisthes digiticeps (Simon, 1881) & European-Ancient Mediterranean \\
\hline Diplocephalus graecus (O. Pickard-Cambridge, 1872) & European-Mediterranean \\
\hline D. protuberans (O. Pickard-Cambridge, 1875$)$ & West European \\
\hline Erigone dentipalpis (Wider, 1834) & Holarctic \\
\hline Frontinellina frutetorum (C.L. Koch, 1834) & West Palaearctic \\
\hline Gnathonarium den tatum (Wider, 1834) & Palaearctic \\
\hline Gonatium occidentale Simon, 1918 & West Mediterranean \\
\hline Improphantes breviscapus Tana sevitch, 2013 & Levantine \\
\hline Lepthyphantes a lbuloides (O. Pickard-Cambridge, 1872) & East Mediterranean \\
\hline Linyphia mimonti Simon, 1884 & East Mediterranean \\
\hline Maculoncus parvipalpus W underlich, 1995 & East Mediterranean \\
\hline Mecopisthes monticola Bosmans, 1993 & Mediterranean \\
\hline M. peusi Wunderlich, 1972 & European \\
\hline Megalepthyphantes kuhitangensis (Tanase vitch, 1989) & East Ancient Mediterranean \\
\hline Mermessus denticulatus (Banks, 1898) & Introduced \\
\hline M. fradeorum (Berland, 1932) & Introduced \\
\hline Microctenonyx subitan eus (O. Pickard-Cambridge, 1875) & European-Ancient Mediterranean \\
\hline Pelecopsis elongata (Wider, 1834) & West Palaearctic \\
\hline P. inedita (O. Pickard-Cambridge, 1875) & Mediterranean \\
\hline P. levantensis sp.n. & Levantine \\
\hline Prinerigone vagans (Audouin, 1826) & Cosmopolitan \\
\hline Sengletus extricatus (O. Pickard-Cambridge, 1876) & East Ancient Mediterranean \\
\hline Silom etopus minutus sp.n. & Levantine \\
\hline S. pectinatus sp.n. & Levantine \\
\hline Styloctetor rom anus (O. Pickard-Cambridge, 1872) & Palaearctic \\
\hline Tenuiphantes tenuis (Blackwall, 1852) & European-Ancient Mediterranean \\
\hline Thaumatoncus secundus Bosmans, 2002 & Mediterranean \\
\hline Trichoncoides piscator (Simon, 1884) & Ancient Mediterranean \\
\hline Trichoncus rostralis Tanase vitch, 2013 & Levantine \\
\hline Troxochrus triangularis Tanase vitch, 2013 & Levantine \\
\hline Typhochrestus meron Tanasevitch, 2013 & Levantine \\
\hline Walckenaeria galilea sp.n. & Levantine \\
\hline W. stylifrons (O. Pickard-Cambridge, 1875) & European \\
\hline
\end{tabular}

tial. Most of the fauna $(47 \%)$ is represented by different kinds of Mediterranean or Ancient Mediterranean forms. The influence of the North African centre of linyphiid diversity on the western Levantine linyphiid fauna is expressed much more strongly than that of the Central Asian one.
ACKNOWLEDGEMENTS. I am most grateful to all persons whose collections have been used in the present study. Special thanks go to Dr Sergei Zonstein (Tel Aviv, Israel) for his help with fieldwork and for useful comments, as well as to Sergei Golovatch (Moscow, Russia) who checked the English of an advanced draft. 


\section{References}

Bosmans R. 2002. Les genres Acartauchenius Simon et Thaumatoncus Simon en Afrique du Nord. Etudes sur les Linyphiidae africaines, no IX (Araneae, Linyphiidae, Erigoninae) // Revue Arachnologique. T.14. P.1-24.

Bosmans R. 2007. Contribution to the knowledge of the Linyphiidae of the Maghreb. Part XII. Miscellaneous erigonine genera and additional records (Araneae: Linyphiidae: Erigoninae) // Bulletin \& Annales de la Société Entomologique de Belgique. T.143. P.117-163.

Bosmans R., Van Keer J., Russell-Smith A., Kronestedt T., Alderweireldt M., Bosselaers J., Koninck H. De. 2013. Spiders of Crete (Araneae). A catalogue of all currently known species from the Greek island of Crete // Nieuwsbrief van de Belgische Arachnologische Vereniging. Deel 28. Suppl.1. S.1-147.

Hormiga G. 2000. Higher level phylogenetics of erigonine spiders (Araneae, Linyphiidae, Erigoninae) // Smithsonian Contributions to Zoology. No.609. P.1-160.

Merrett P. 1963. The palpus of male spiders of the family Linyphiidae // Proceedings of the Zoological Society of London. Vol.140. P.347-467.

Tanasevitch A.V. 2013. On linyphiid spiders (Araneae) from Israel // Revue suisse de Zoologie. T.120. Fasc.1. P.101-124.

Zonstein S.L., Marusik Yu.M. 2013. Checklist of the spiders (Araneae) of Israel // Zootaxa. Vol.3671. No.1. P.1-127.

Zonstein S.L., Marusik Y.M., Omelko M.M. 2015. A survey of spider taxa new to Israel (Arachnida: Araneae) // Zoology in the Middle East. Vol.61. No.4. P.372-385.

Responsible editor K.G. Mikhailov 